\title{
SEMIOLOGIA
}

\section{Glosario semiológico en Dermatología (XIX)}

\section{Ester Avayú1, Francisco Urbina ${ }^{2}$, Rosamary Soto ${ }^{3}$}

'Dermatóloga CRS Cordillera Oriente Peñalolén, Clínica Indisa, Docente Universidad de Chile, Sede Oriente. ${ }^{2}$ Dermatólogo en práctica privada, Santiago. ${ }^{3}$ Dermatóloga, Profesor Asistente de Dermatología Universidad de Chile, CRS Cordillera Oriente.

El glosario semiológico en Dermatología es la recopilación parcelada de una gran cantidad de lesiones, signos, epónimos, analogías y comparaciones con las que se describen los diversos procesos de nuestra especialidad.

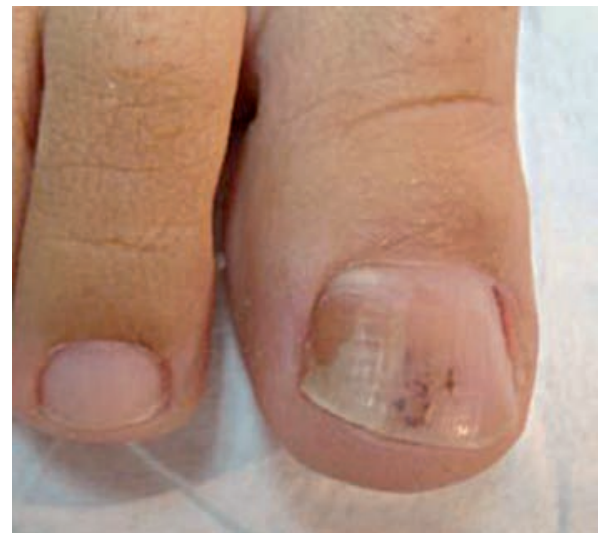

Hemorragias en astilla: finas líneas longitudinales de color rojo oscuro, localizadas en las regiones distales de las uñas. Aparecen en relación con traumas, psoriasis y onicomicosis. Hacia proximal son raras y se producen por endocarditis bacteriana o vasculitis.

Líneas mamilares: desde el pliegue axilar anterior hasta la parte medial de la porción superior del muslo se pueden encontrar pezones supernumerarios y tejido mamario accesorio, constituyendo restos de las crestas mamarias embriológicas.

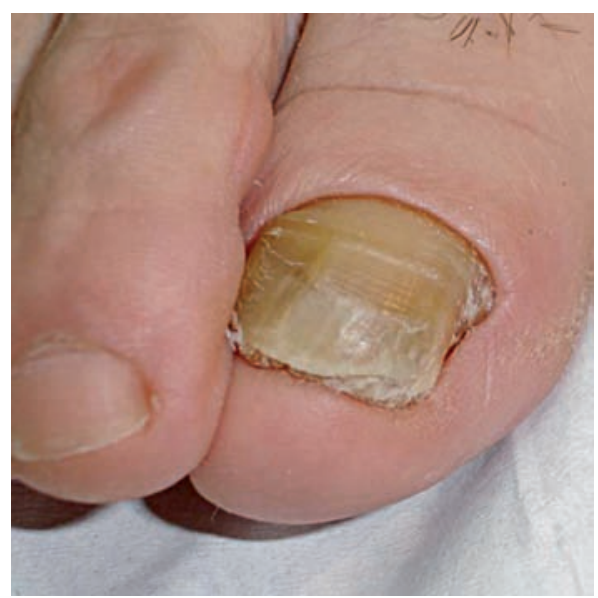

Onicocauxis: uñas engrosadas con formación de escamas subungueales. Se observa en psoriasis y onicomicosis.

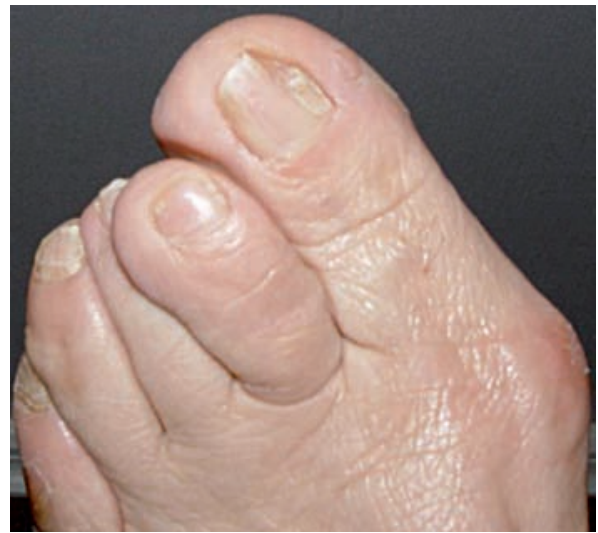

Onicofosis: material hiperqueratósico localizado o difuso que aparece en la vejez, afectando los bordes de los pliegues proximales o laterales de los dedos de los pies, generalmente los primeros o los quintos, hacia la lámina ungueal.

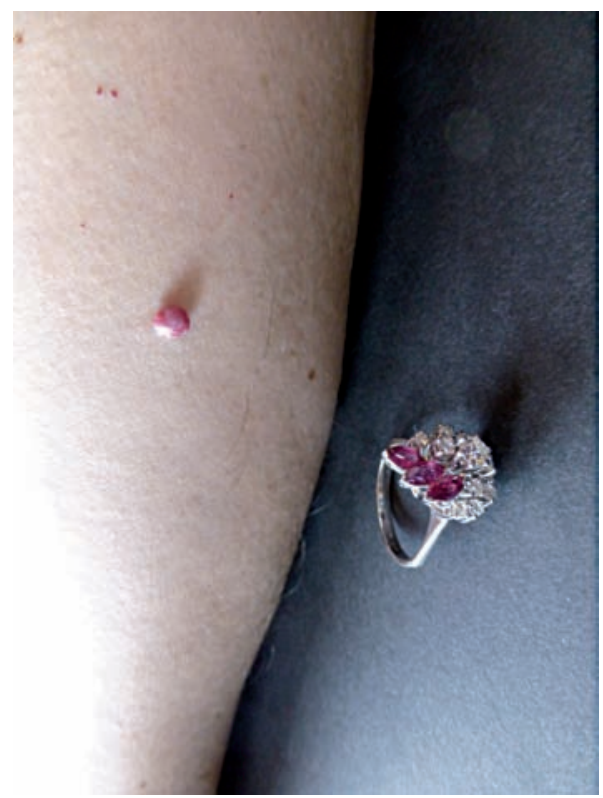

Punto rubí: pápula cupuliforme rojiza, de unos pocos milímetros de diámetro, localizada en tronco y miembros superiores. También se conoce como angioma eruptivo, de presentación frecuente y carácter benigno.

Rev. Chilena Dermatol. 2015; 31 (4) : 399 - 400 


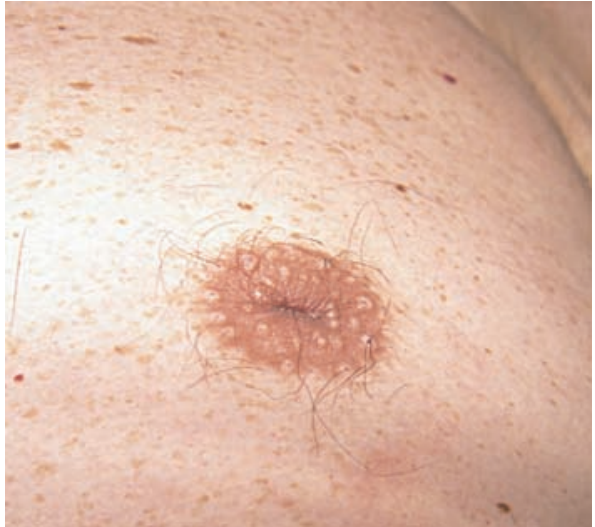

Signo de Forgue: consiste en la retracción unilateral y adquirida del pezón, siendo un signo característico de cáncer mamario.

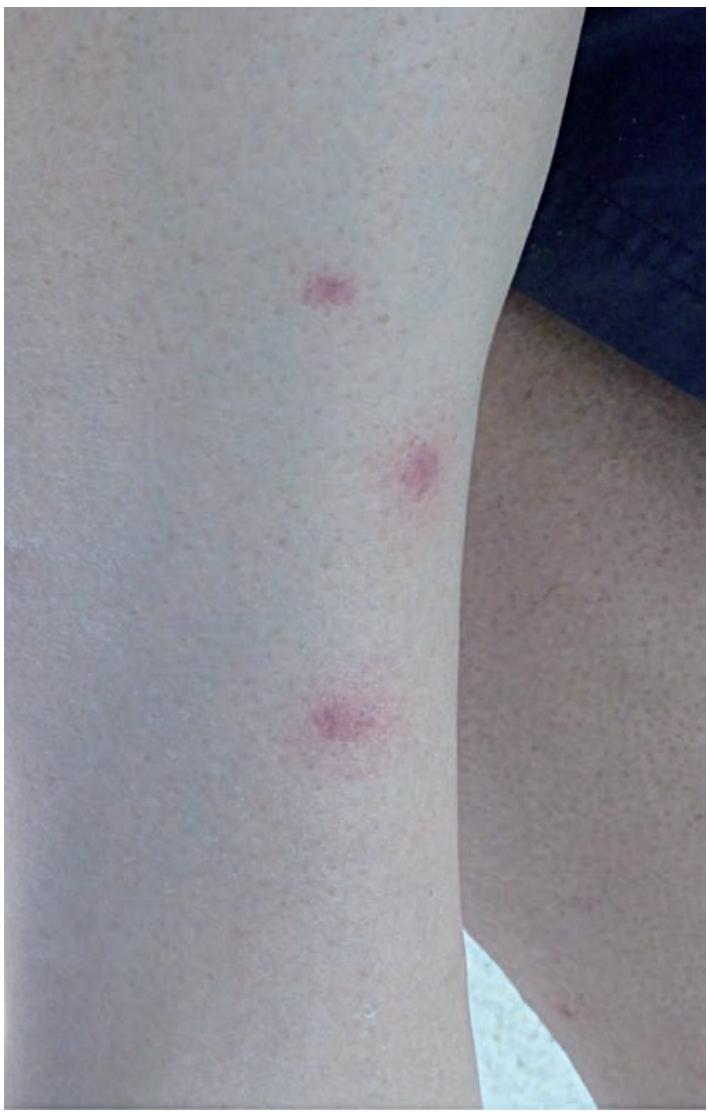

Signo del desayuno-comida-y-cena: lesiones papulosas, habonosas o ampollares, agrupadas o con distribución lineal, una tras otra, que se producen tras las picaduras de insectos hematófagos.

Signo flagellata (o aspecto de cebra): presenta lesiones eritematosas lineales y entrecruzadas, urticariformes, especialmente en tronco. Se produce en la dermatomiositis.
Síndrome de la boca ardiente: se produce ardor crónico de los bordes y la punta de la lengua, paladar y labios. No se encuentra alguna causa específica que lo provoque. En muchos casos existen problemas psiquiátricos de base y en algunos, cancerofobia 0 antecente de fallecimiento reciente de algún familiar por algún tipo de cáncer.

Síndrome del hombre rojo: erupción maculopapular en región cervical, cara y extremidades, con edema generalizado, producido tras infusión rápida de vancomicina.

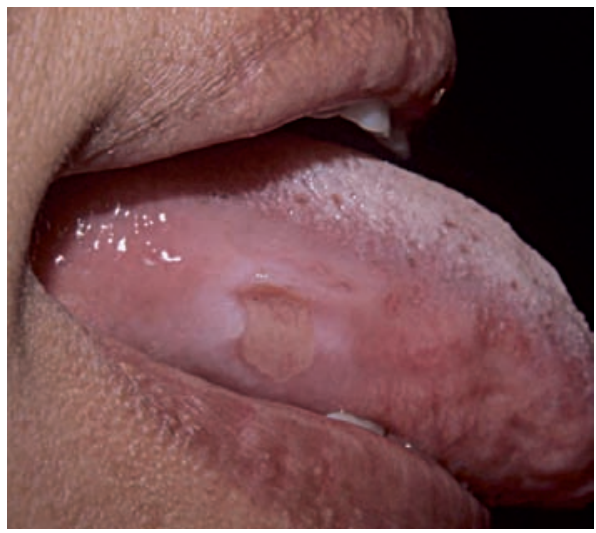

Úlcera eosinofílica de la lengua: úlcera de la lengua de etiología desconocida que se presenta como una lesión de alrededor de 1,5 centímetros de diámetro, localizada en el dorso, zona ventral o borde de la lengua y que muestra una resolución espontánea. El principal diagnóstico diferencial es el cáncer de lengua. Su histopatología muestra un infiltrado inflamatorio mixto de la submucosa, con predominio característico de eosinófilos.

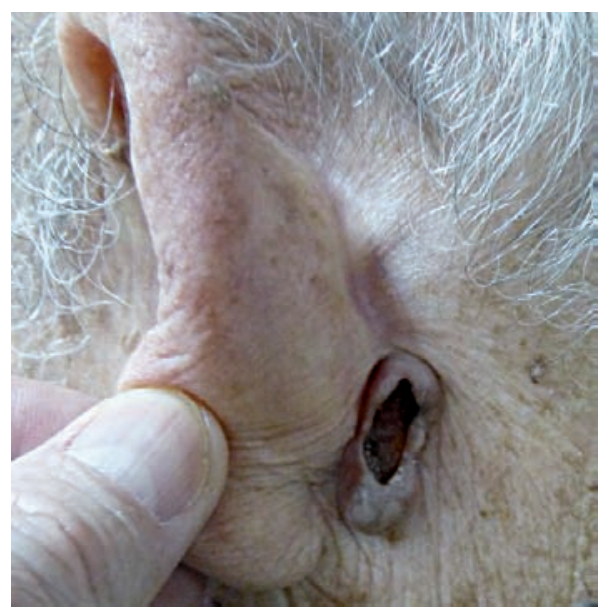

Ulcus rodens: variedad de carcinoma basocelular caracterizado por una úlcera localizada habitualmente en la cara, rodeada de tejido infiltrante sobreelevado con telangiectasias. También se conoce como úlcera de Jacob, quien la describió en 1827, o úlcera del roedor. 